\title{
Optimization of Flat Plate Solar Dryer using Taguchi Method
}

\author{
Ankit Bansal, Umesh Gupta, Sandeep Singh
}

\begin{abstract}
Solar form of energy is the most broadly used renewable forms around the globe. The present paper includes the utilization of solar energy in drying food item using a flat plate solar dryer. The experiment is carried with every hour interval and the readings are noted down. The study comprises of timing from morning 9 am to evening $6 \mathrm{pm}$. Around $10 \mathrm{~kg}$ of chilli is utilized for the drying purpose. The outcome results were optimized using Taguchi method to identify the optimum configurations for the drying effect. The result shows that, Ambient temperature as 35.5 OC value of air velocity Ambient Relative Humidity as 67.4(\%) and Exhaust temperature as 54.2 OC after optimization. Also, the maximum intensity of solar rays are obtained during the daytime at 1 pm.
\end{abstract}

Keywords : Solar, flat plate, Taguchi, drying, optimization.

\section{INTRODUCTION}

Drying and dehydrating is the most significant route which is need to be performed on daily basis where dehydrating take out the moisture available in food items which increase the life of dried products and in comparison to fresh food items. (Majdi and Esfahani, 2018). In drying procedure some variations takes place includes chemical as well as physical and complex too when it go through the estimation depends on numerous points i.e temperature, moisture and time etc. drying process goes through strong track of moisture content needs to be performed under direct radiation of sun. This aspect evaluates the dehydration of food items. (Padmanaban and Palani, 2017).

Some farming products contains very high ratio of moistures and therefore it appears fresh and consumable. Addition and reduction of water with thought of decaying factors is one of the few constituents in the mind of developing countries should loss of such products depends mainly on tropical regions and in subtropical regions. Those losses are mainly of lack of storage facility, rough handling, transportation and many other reasons (Sharma, Garg and Kumar, 2018). Whereas it could be said that, the countries that move towards to be in the race of developing countries

\section{Revised Manuscript Received on April 04, 2020.}

* Correspondence Author

Dr. Ankit Bansal*, Associate Professor, Vaish College of Engineering, Rohtak, India

Dr. Umesh Gupta, Associate Professor, Vaish College of Engineering, Rohtak, India

Sandeep Singh, Asstt. Professor, Vaish College of Engineering, Rohtak, India

(C) The Authors. Published by Blue Eyes Intelligence Engineering and Sciences Publication (BEIESP). This is an open access article under the CC BY-NC-ND license (http://creativecommons.org/licenses/by-nc-nd/4.0/) able to declining losses related to the agriculture and food areas and improve the qualities of the products to be dried. (Aghaie, Rahimi and Akbarzadeh, 2015)

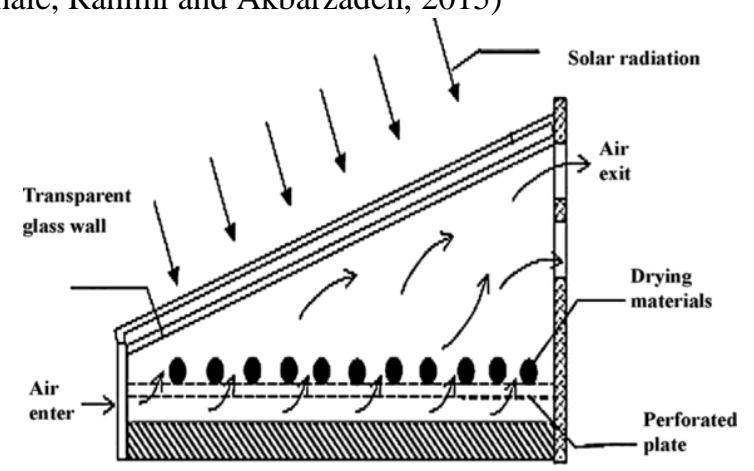

Fig. 1.Solar dryer diagram.

\section{A. Optimization of solar dryers}

As the technologies grown solar dryers also enhanced with new design and techniques gives high performance and efficiency working in short span of time. The time period should be important aspect as it makes it highly efficient. (Chen et al. 2011). This leads to attain better results with high performance in solar dryers as compared in traditional techniques which consume very long period of time. This extension regarding the solar based dryer might allow several techniques such as linear regression, in addition with genetic algorithm, including the grey relation analysis and also in Taguchi techniques etc.(Bakari, Minja and Njau,2014).

\section{LITERATURE REVIEWS}

(Dalvand, Mohtasebi, \& Rafiee, 2014) Solar drying usage of products of agriculture which is performed on based upon their moisture contents. Electro Hydro Dynamic linked to PV unit a new technique used for the drying application. In these particular techniques the range of voltage $6-15 \mathrm{KV}$ was introduced in the system framework utilized for the purpose of drying the item in the drying chamber. The entire experiment was enhanced by the means of techniques implemented to develop surface based results which declines the time consumption and is cost effective.

(Verma, Murugesan, \& Kumar Kakati, 2019) Research paper presents a study on the efficiency of solar since it can add so much in their scalar powered system field. The research is still race in the field of use of applications based upon solar researchers. Space heating techniques presented in this research by solar coupled by heat pump (SCHP). 
Indian climatic condition used and measured for this purpose. Different constraints of the solar units are improved by the means of developed technique known as Taguchi. Five different constraints used to analyse the best results in this study.

From the study coefficient of performance of the system and efficiency of whole system varies from $38 \%$ to $61 \%$ and also $1.9 \%$ to 3.01\% respectively. In Taguchi method, the L27 orthogonal matrix is implemented for the selection of optimum working parameters. From the result outcomes, it was observed that, alteration in the outcomes was observed because of difference in the constraints.

(Liu et al., 2019) In this study which is based on examination and presentation seen in hybrid system consist of PCM with a ventilated tromb wall. The entire parametric constraints regarding the hybrid system were enhanced and developed to obtain the best suited outcomes to work on these configurations. This research work was carried out experimentally depending on the simulations carried out mathematically and numerical basis. The work included a formation of L9 matrix using the Taguchi method. A total number of nine models were made having varying parameter configuration. The analysis was carried out using the graphical representations of ANOVA. The key components considered in the study utilizing the PCM thickness parameter. The optimum value obtained from the complete research was mass flow rate of about $1 \mathrm{~kg} / \mathrm{s}$, the dimensions of pipe with $0.6 \mathrm{~m}$ in dia.,and temperature of 15 degree Celsius with the thickness of the PCM as $20 \mathrm{~cm}$.

Table- I: Research done by previous researchers in optimization of solar dryers

\begin{tabular}{|c|c|c|c|c|c|c|}
\hline Year & $\begin{array}{l}\text { Author } \\
\text { Name }\end{array}$ & Method used & Model & Data set & $\begin{array}{l}\text { Moisture removing } \\
\text { rate }(\mathrm{MRR})\end{array}$ & Outcome \\
\hline 1. & $\begin{array}{l}\text { Foued } \\
\text { Chabane } \\
(2019)\end{array}$ & $\begin{array}{l}\text { "A method of } \\
\text { drying of } \\
\text { apricot from } \\
\text { vaporisation." }\end{array}$ & $\begin{array}{l}\text { "A } 15 \mathrm{~mm} \text { thicken } \\
\text { box made of wood } \\
\text { used for sensor with } \\
153 \mathrm{~cm} \times 83 \times \mathrm{xm} 10 \\
\mathrm{~cm} \text { in size } \\
\text { respectively" }\end{array}$ & Apricot & $\begin{array}{l}\text { The moisture rate is } \\
0.15 \text { and } 0.2 \text { having a } \\
\text { total quantity of apricot } \\
370 \text { and } 456 \mathrm{gm} \\
\text { respectively }\end{array}$ & (Chabane et al., 2019) \\
\hline 2. & $\begin{array}{l}\text { (Osodo \& } \\
\text { Nyaanga, } \\
\text { 2018) }\end{array}$ & $\begin{array}{l}\text { "It was analysed } \\
\text { with a deviation } \\
\text { of MRR used as } \\
\text { ANOVA and } \\
\text { LSD" }\end{array}$ & $\begin{array}{l}1.2 \mathrm{~m} \times 1.8 \mathrm{~m} \times 0.1 \mathrm{~m} \\
\text { height respectively } \\
\text { calculated as area of } \\
\text { the air vent }\end{array}$ & Grain & $\begin{array}{l}0.061 \text { to } 0.022 \\
\text { moisture per } \\
\text { an hour }\end{array}$ & $\begin{array}{l}\text { "Grain layer thickness } \\
\text { increased } \\
\text { from } 0.02 \text { to } 0.08 \mathrm{~m} \\
\text { respectively for } 0.212 \mathrm{~m} / \mathrm{s} \text { with } \\
\text { flow rate as } 0.22 \mathrm{~kg} \text { of wt. grain/ } \\
\text { hour". }\end{array}$ \\
\hline 3. & $\begin{array}{l}\text { (Majdi \& } \\
\text { Esfahani, } \\
\text { 2018) }\end{array}$ & $\begin{array}{l}\text { Projected a } \\
\text { theory of } \\
\text { removing liquid } \\
\text { by Numerical } \\
\text { simulation } \\
\text { method and this } \\
\text { process is } \\
\text { further } \\
\text { enhanced by } \\
\text { Taguchi's } \\
\text { method } \\
\text { providing a } \\
\text { solution with } \\
\text { LBM technique } \\
\text { implemented to } \\
\text { solve hydro } \\
\text { dynamically, } \\
\end{array}$ & $\begin{array}{l}\mathrm{L} \text { X B X H }=4 \mathrm{~cm} \text { X } 1 \\
\mathrm{~cm} \quad \mathrm{X} \quad 1 \quad \mathrm{~cm} \\
\text { respectively }\end{array}$ & apple & $\begin{array}{l}\text { Final Drying maximum } \\
\text { efficiency recorded as } \\
74.3 \% \text { with } 3.5 \mathrm{~m} / \mathrm{s} \text { fan }\end{array}$ & $\begin{array}{l}\text { "As per The Taguchi's design } \\
\text { the final ideal conditions found } \\
\text { which is in temperature is } 60 \\
\text { degree Celsius, Velocity is } \\
0.1 \mathrm{~m} / \mathrm{s} \text { and thickness as } \\
\text { resulted as final optimized is } \\
\text { equal as TR-0.1.It shows the } \\
\text { minimal energy depletion" }\end{array}$ \\
\hline 4. & $\begin{array}{l}\text { (Obayopo \& } \\
\text { Alonge, } \\
\text { 2018) }\end{array}$ & $\begin{array}{l}\text { "An } \\
\text { implementation } \\
\text { of using one } \\
\text { way to two way } \\
\text { as a study of } \\
\text { alteration by } \\
\text { ANOVA } \\
\text { process get } \\
\text { resulted by } 95 \% \\
\text { confidence level } \\
(\mathrm{P}<0.05) . "\end{array}$ & $\begin{array}{l}\text { It was double walled } \\
\text { by double insulated } \\
\text { having a fibre glass } \\
\text { cylinder to stop } \\
\text { energy losses } \\
\text { measured as L x W x } \\
\mathrm{H}=70 \mathrm{~cm} \text { x } 60 \mathrm{~cm} \mathrm{x} \\
40 \mathrm{~cm} \text { respectively. }\end{array}$ & $\begin{array}{l}\text { catfish } \\
\text { (Clariasgarie } \\
\text { pinus) and } \\
\text { tilapia fish } \\
\text { (Oreochromi } \\
\text { sniloticus }\end{array}$ & $\begin{array}{l}\text { Final Drying maximum } \\
\text { efficiency measured as } \\
74.3 \% \text { with } 3.5 \mathrm{~m} / \mathrm{s} \text { fan }\end{array}$ & $\begin{array}{l}\text { "It has been proven that the } \\
\text { solar glass would be a better } \\
\text { unconventional methodology } \\
\text { and used as a tool for } \\
\text { conserving of different kinds of } \\
\text { fishes which are meant } \\
\text { providing nourishment and } \\
\text { growth. }\end{array}$ \\
\hline 5. & $\begin{array}{l}\text { (Macías-ganc } \\
\text { hozo et al., } \\
2018 \text { ) }\end{array}$ & $\begin{array}{l}\text { "A tabulated } \\
\text { result is used in } \\
\text { foster TM and } \\
\text { star Graphics } \\
5.1 \mathrm{TM} \text { software } \\
\text { to compute } \\
\text { linear } \\
\text { regression and } \\
\text { variance." }\end{array}$ & $\begin{array}{l}\text { Measured as } 0.5 \mathrm{~m} \mathrm{x} \\
0.5 \mathrm{~m} \times 1 \mathrm{~m} \text { solar dryer } \\
\text { is used }\end{array}$ & $\begin{array}{l}\text { Banana } \\
\text { pineapple }\end{array}$ & $\begin{array}{l}\text { Banana } 80.22 \% \\
\text { pineapple } 86.36 \\
\text { The various task } \\
\text { enhancing process } \\
\text { constraint }\end{array}$ & $\begin{array}{l}\text { "Experiments was perform and } \\
\text { establish the molecular } \\
\text { structure of the banana" }\end{array}$ \\
\hline
\end{tabular}




\begin{tabular}{|c|c|c|c|c|c|c|}
\hline 6. & $\begin{array}{l}\text { (Padmanaban } \\
\& \quad \text { Palani, } \\
\text { 2017) }\end{array}$ & $\begin{array}{l}\text { "Taguchi } \\
\text { Method \& Grey } \\
\text { Relational } \\
\text { Analysis" }\end{array}$ & $\begin{array}{l}\text { In Grey Relation } \\
\text { Analysis we found } \\
\text { multiple results in the } \\
\text { process of } \\
\text { optimization } \\
\text { constraints was } \\
\text { perform for drying } \\
\text { with the help of } \\
\text { reducing moisture } \\
\text { content rate }\end{array}$ & potato & $\begin{array}{l}\text { is } 37.36 \% \text { and } 32.28 \\
\%\end{array}$ & $\begin{array}{l}\text { "The parameters combination } \\
\text { had suggests for the high WRR } \\
\text { and less Moisture } \\
0 \\
\text { Content have an Initial mass of } \\
500 \text { g, inclination angle of } 30 \\
\text { and time period 1-2 AN." }\end{array}$ \\
\hline 7. & $\begin{array}{l}\text { (Salvatierra-R } \\
\text { ojas et al., } \\
2017 \text { ) }\end{array}$ & $\begin{array}{l}\text { "Overall } \\
\text { comparisons } \\
\text { was evaluate by } \\
\text { Duncan's } \\
\text { Multiple Range } \\
\text { test for milling } \\
\text { Head rice yield } \\
\text { by conducting it } \\
\text { on the } \\
\text { (ANOVA)." }\end{array}$ & $\begin{array}{l}\text { The inflatable solar } \\
\text { dryer (ISD) was } \\
\text { developed within } \\
\text { The framework of a } \\
\text { cooperation project. }\end{array}$ & paddy rice & $\begin{array}{l}\text { In drying Head rice } \\
\text { yield resulted is } 57.7 \%\end{array}$ & $\begin{array}{l}\text { "The experiment presented } \\
\text { shows a } 1000 \mathrm{~kg} \text { paddy might be } \\
\text { utilized with ease in addition } \\
\text { with } 14 \% \text { moisture content in } \\
\text { rainy climate conditions. }\end{array}$ \\
\hline 8. & $\begin{array}{l}\text { (Ndukwu \& } \\
\text { Bennamoun, } \\
\text { 2017) }\end{array}$ & "ANOVA" & $\begin{array}{l}\text { Drying chamber } \\
\text { measured as } 1000 \\
\text { mm x } 500 \mathrm{~mm} \text { and a } \\
\text { solar collector } 500 \\
\text { mm x 500 mm } \\
\text { respectively }\end{array}$ & Red chilli & $\begin{array}{l}\text { Sodium Sulphate Dec } \\
\text { hydrate } 7.6-10 \% \text {. } \\
26.7 \% \text { and } 39 \% \\
\text { compared to drying } \\
\text { with } \mathrm{Na} \mathrm{Cl}\end{array}$ & $\begin{array}{l}\text { " } 88 \text { - } 144 \text { hours need to get } \\
\text { drying the Red chili to its } \\
\text { moisture level of about } \\
7.6-10 \% \text {. Drying with } \\
\text { Na2SO4.10H2O as thermal } \\
\text { energy storage reduced. The } \\
\text { drying time by } 26.7 \% \text { and } 39 \% \\
\text { was compare to drying with } \\
\text { NaCl and without any thermal } \\
\text { storage." }\end{array}$ \\
\hline 9. & $\begin{array}{l}\text { (N. et al., } \\
2016)\end{array}$ & $\begin{array}{l}\text { "TVC, TFC, } \\
\text { TVN and TMA } \\
\text { were analyze } \\
\text { using Study of } \\
\text { Variance } \\
\text { (ANOVA). } \\
\text { Post-hoc } \\
\text { Tukey's test } \\
\text { applied", }\end{array}$ & $\begin{array}{l}\text { It has dimensions of } \\
1 \mathrm{~m} \times 1 \mathrm{~m} \text { area }\end{array}$ & Fish & $\begin{array}{l}\text { reduction in moisture } \\
\text { content from } 80 \% \text { to } \\
15 \%\end{array}$ & $\begin{array}{l}\text { "Experimentally dried fish } \\
\text { samples by SCD, HAD and FD } \\
\text { are of better microbial and } \\
\text { biochemical quality as } \\
\text { compared to the traditionally } \\
\text { open sun dried fish in context to } \\
\text { the parameters analyzed." }\end{array}$ \\
\hline 10. & $\begin{array}{l}\text { (Dhumne et } \\
\text { al., 2016) }\end{array}$ & $\begin{array}{l}\text { "GA approach } \\
\text { employed to } \\
\text { optimize the } \\
\text { solar tunnel } \\
\text { dryer for drying } \\
\text { red chilies." }\end{array}$ & $\begin{array}{l}\text { Aluminum sheet with } \\
\text { a value of } \\
\text { Absorptivity was } \\
0.15 \text { The layer } \\
\text { thickness of chilies } \\
\text { maintained at } 20 \mathrm{~cm} .\end{array}$ & red chilies & M R \% 45.49 & $\begin{array}{l}\text { "The optimization of solar } \\
\text { tunnel dryer for removing the } \\
\text { water from red chilies } \\
\text { employed by geometric } \\
\text { algorithm and for the particular } \\
\text { method geometric algorithm } \\
\text { established" }\end{array}$ \\
\hline 11. & $\begin{array}{l}\text { (Monteiro et } \\
\text { al., 2016) }\end{array}$ & $\begin{array}{l}\text { "Statistica } 7.0 \\
\text { (StatSoft, in } \\
\text { addition with } \\
\text { ANOVA test" }\end{array}$ & $\begin{array}{l}\text { (Electrolux, Model } \\
\text { MEX55, Brazil), at } \\
\text { power level of } 700 \mathrm{~W} \text {. } \\
\text { the magnetron is } \\
\text { "on", for } 20 \mathrm{~s} \text { and } \\
\text { "off" for } 9 \mathrm{~s} \text {, while at } \\
400 \mathrm{~W} \text { the magnetron } \\
\text { is "on" for } 11 \mathrm{~s} \text { and } \\
\text { "off" for } 18 \mathrm{~s} \text {. }\end{array}$ & Banana & $\begin{array}{l}\text { The items were dried } \\
\text { by the MWVD as well } \\
\text { as MWMFD depicting } \\
\text { the declination of } 27 \% \\
\text { \& } 36 \%\end{array}$ & $\begin{array}{l}\text { "the values from the samples of } \\
\text { MWMFD were } 20-50 \% \text { greater } \\
\text { compared to developed samples } \\
\text { of MWVD. } \\
\text { " }\end{array}$ \\
\hline 12. & $\begin{array}{l}\text { (Hammond et } \\
\text { al., 2018) }\end{array}$ & $\begin{array}{l}\text { "By Solver's } \\
\text { function and } \\
\text { ANOVA } \\
\text { statistics } \\
\text { method and a } \\
\text { series solution } \\
\text { of Fick's second } \\
\text { law and } \\
\text { calculation } \\
\text { performed } \\
\text { using Excel's } \\
\text { inbuilt" }\end{array}$ & $\begin{array}{l}\text { Measured as } 3 \mathrm{~cm} \text { x5 } \\
\mathrm{cm} \text { torn samples and } \\
2 \mathrm{~cm} \times 2 \mathrm{~cm} \text { cut } \\
\text { samples }\end{array}$ & algae & & $\begin{array}{l}\text { "The removal of dehydrating } \\
\text { rate and the layer thickness } \\
\text { decreases. The Experimental } \\
\text { data was model using an } \\
\text { analytical series solution of } \\
\text { Fick's second Law with the } \\
\text { effective diffusivity of } 5 \times 10-9 \\
\text { m2/s Approx." }\end{array}$ \\
\hline
\end{tabular}

Published By:

Blue Eyes Intelligence Engineering \& Sciences Publication

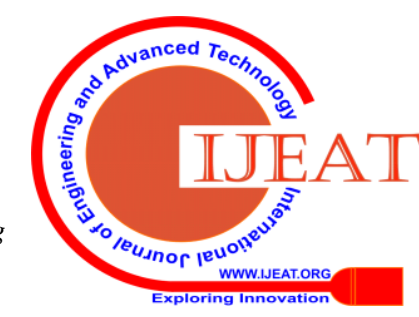




\begin{tabular}{|c|c|c|c|c|c|c|}
\hline 13. & $\begin{array}{l}\text { (Zebib et al., } \\
\text { 2017) }\end{array}$ & $\begin{array}{l}\text { "2 way analysis } \\
\text { of variance } \\
\text { (ANOVA) used } \\
\text { to calculate" }\end{array}$ & $\begin{array}{l}\text { Measured as } 50 \mathrm{~cm} x \\
1 \mathrm{~cm} \times 60 \mathrm{~cm} \text { in area } \\
\text { with a wooden frame } \\
\text { poles of } \\
\text { Capacity } 5000 \mathrm{~g} \mathrm{x} 0.1 \\
\mathrm{~g}\end{array}$ & Tilapia fish & $\begin{array}{l}\text { Moisture loss (\%) } \\
79.54\end{array}$ & $\begin{array}{l}\text { "In Comparison to tilapia fillet } \\
\text { product } \\
\text { Open air dryer showed high } \\
\text { moisture content rate revealed } \\
\text { the most acceptable product } \\
\text { obtained from brined product } \\
\text { sensory evaluation further } \\
\text { raised rack tent dryer which } \\
\text { produces better result in drying } \\
\text { of water in five day process" }\end{array}$ \\
\hline 14. & $\begin{array}{l}\text { (Vásquez et } \\
\text { al., 2016) }\end{array}$ & $\begin{array}{l}\text { "The dryer was } \\
\text { advance } \\
\text { predictive fuzzy } \\
\text { logic control } \\
\text { system" }\end{array}$ & $\begin{array}{l}\text { The specifications of } \\
\text { solar chamber: } 1.2 \mathrm{~m} \\
\text { x } 2.9 \mathrm{~m} \times 0.07 \mathrm{~m} \text {. } \\
\text { there were } 40 \text { zinc } \\
\text { fins in black, each of } \\
0.03 \times 0.025 \mathrm{~m}\end{array}$ & $\begin{array}{l}\text { Peach } \\
\text { Drying } \\
\text { Mushroom } \\
\text { Drying Plum } \\
\text { Drying Ten }\end{array}$ & $88 \%$ & $\begin{array}{l}\text { "Mushroom moisture content } \\
\text { reduction rate decrease from } \\
85 \% \text { to } 10 \% \text {. } \\
\text { Plum moisture content } \\
\text { reduction rate decrease from } \\
79 \% \text { to } 70 \% \text { and peaches } 86 \% \\
\text { to } 55 \% \text {." }\end{array}$ \\
\hline 15. & $\begin{array}{l}\text { (Khama et al., } \\
\text { 2016) }\end{array}$ & $\begin{array}{l}\text { "Anova method } \\
\text { is used to } \\
\text { implement the } \\
\text { result" }\end{array}$ & $\begin{array}{l}\text { indirect solar dryer } \\
\text { External dimensions } \\
1.90 \times 1.14 \times 0.16 \mathrm{~m}\end{array}$ & Tomato & $66.56 \%$ & $\begin{array}{l}\text { "The moisture content } \\
\text { reduction rate of the tomatoes } \\
\text { reduced from } 14.32 \text { to } 0.14 \mathrm{~kg} \\
\text { water/ kg dry matter after } 12 \mathrm{~h} \\
\text { of drying time." }\end{array}$ \\
\hline
\end{tabular}

\section{METHODOLGY}

The included dryer that was made in this research was made with the help of PVC sheet which is defiant for covering the dryer chamber and collector, angle bar and square bar for making the structure, polythene film, wheels for moving the dryer easily, nuts and bolts for joining the different parts, poly coated wire net, corrupted iron sheet, paint for making the dryer rust proof, solar panel etc. The dryer needs to be bare in the open air. Therefore the dryer must be resistive from the weathering. Other serious topic is to focus the dryer for managing appropriateness. The PVC sheet is very light and resistive to water. According to the parameter of design there needed $4.3 \mathrm{~m}^{2}$ of PVC sheet of $12 \mathrm{~mm}$. The angle bar was mainly used as the supporting structure of the dryer. The whole dryer structure was supported by the angle bar. There need a $13.5 \mathrm{~m}$ of angle bar $(3.16 \mathrm{~cm})$ for constructing of collector as well as $41.2 \mathrm{~m}$ of angle bar $(3.18 \mathrm{~cm})$ for construction of dryer chamber. Mainly the square bars were used in the trays. It was also used in the polythene. They require $51.5 \mathrm{~cm}$ of square bar $(8 \mathrm{~mm})$ for making the 4 trays and $25.5 \mathrm{~cm}$ of square bar $(8 \mathrm{~mm})$ for making the roof of the dryer. The polythene is an essential component for trapping solar energy to the dryer. The solar incident of short wavelength enters through the polythene sheet also make the chamber hot. The long wavelength generates into the dryer then intent and makes the chamber hotter. The polythene film also protects from migration of dust or microorganisms into the dryer. There was used $6.2 \mathrm{~m}^{2}$ of polythene film $(1.5 \mathrm{~mm}$ thick) both in the dryer and collector.
SIDE GLASS

COVER

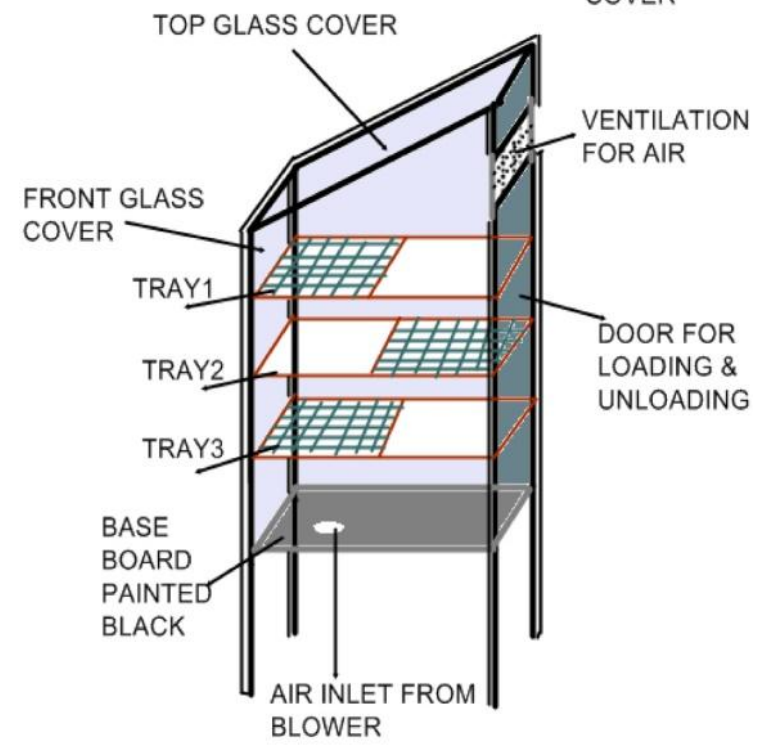

Fig. 2.Flat plate Solar Dryer

Heavy rollers are used to maintain this whole structure so that it can be moved from one place to another. Total number of wheels to be 10 of diameter $100.6 \mathrm{~mm}$ which will be used for sustaining this structure. The fixation of dryer component was made by nuts and bolts. This type of fixation endures easiness of handling of all the parts as they can be repaired and replaced when required. The dryer and collector were fixed with nut and bolt so that transportation can be made easily. The required number of piece is 100 with a diameter of 11.7 mm nut and bolt and 20 pieces of $24.4 \mathrm{~mm}$ diameter nut and bolt. The wire net is the supporter of the trays which is poly coated. The needed $14.2 \mathrm{~m}^{2}$ of plastic coated mesh. With the help of coating on the wire net of poly it makes the net stainless and resistive to weathering. The corrugated iron (CI) sheet was kept at the collector. The angle of the collector was $33.25^{\circ}$ with horizon. The CI sheet is also placed with an angle of $33.25^{0}$.

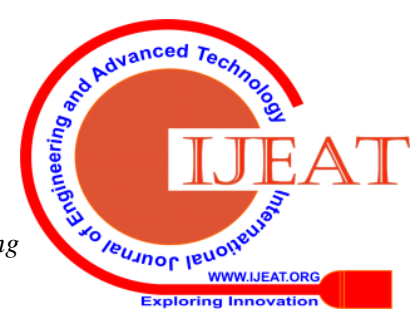


The main motive of using CI sheet was to increase the surface area of the collector so that more solar radiation can be absorbed to generate more heat. The overall dimensions of $\mathrm{CI}$ sheet were $1500 \mathrm{~mm} \times 2700 \mathrm{~mm} \times 1 \mathrm{~mm}$. The CI sheet was painted with a black paint. The paint absorbs the solar radiation and heats of the chamber. The yellowish color was used to the MS bar for protecting of metal from corrosion. The yellowish color was used to the MS bar for safeguarding of metal from corrosion. The dimension of solar panel was
$609.6 \mathrm{~mm} \times 304.8 \mathrm{~mm} \times 25.4 \mathrm{~mm}$. The CAD and prototype of the solar dryer is shown below in the figure 2

\section{RESULT AND DISCUSSION FOR CHILLI DRYING}

The field data during experiment was taken \& shown in the following table.

Table- II: Field Investigation Data

\begin{tabular}{|c|c|c|c|}
\hline SN & Parameter & Symbol & Value \\
\hline 1 & Final Mass of Product & $\mathrm{M}_{\mathrm{wf}}$ & $3 \mathrm{~kg}$ \\
\hline 2 & Pressure Head & $\mathrm{h}$ & $1.5 \mathrm{~m}$ \\
\hline 3 & Temperature inside the dryer & $\mathrm{T}_{\mathrm{i}}$ & $45.5^{0} \mathrm{C}$ \\
\hline 4 & Ambient Temperature & $\mathrm{T}_{\mathrm{am}}$ & $27^{0} \mathrm{C}$ \\
\hline 5 & Collector Temperature & $\mathrm{T}_{\mathrm{c}}$ & $87^{0} \mathrm{C}$ \\
\hline
\end{tabular}

Table- III: Calculated data \& Parameter Estimation

\begin{tabular}{|c|c|c|c|c|c|}
\hline SN & & imeter & Equation & Symbol & Value \\
\hline 1. & \multicolumn{2}{|c|}{ Moisture to be removed from chilli } & 2 & $\mathrm{M}_{\mathrm{r}}$ & $7.03 \mathrm{~kg}$ \\
\hline 2. & \multicolumn{2}{|c|}{ Final moisture of chilli } & & $\mathrm{M}_{\mathrm{i}}$ & $12.7 \%$ \\
\hline 3. & \multicolumn{2}{|c|}{ Pressure throughout the drying bed } & 5 & $\mathrm{P}$ & $0.346 \mathrm{~Pa}$ \\
\hline 4. & \multicolumn{2}{|c|}{ Energy Requirement } & 6 & $\mathrm{E}$ & $16824 \mathrm{KJ}$ \\
\hline \multirow[t]{3}{*}{5.} & \multirow{3}{*}{ Collector } & Area & 8 & $\mathrm{~A}_{\mathrm{c}}$ & $3.2 \mathrm{~m}^{2}$ \\
\hline & & Length & 9 & $\mathrm{~L}_{\mathrm{c}}$ & $2.1 \mathrm{~m}$ \\
\hline & & Width & Assumed & $\mathrm{W}_{\mathrm{c}}$ & $1.4 \mathrm{~m}$ \\
\hline 6. & \multicolumn{2}{|c|}{ Collector useful heat energy gain } & 10 & $\mathrm{Q}$ & $8553 \mathrm{KJ}$ \\
\hline 7. & \multicolumn{2}{|c|}{ Drying rate \& average drying rate } & 11 & $\mathrm{D}_{\mathrm{r}}$ & $0.702 \mathrm{~kg}$ \\
\hline \multirow[t]{5}{*}{8.} & \multirow{5}{*}{ Dryer } & Drying Area & 16 & $A_{d}$ & $2.5 \mathrm{~m}^{2}$ \\
\hline & & Number of Tray & Assumed & $\mathrm{N}_{\mathrm{t}}$ & 4 \\
\hline & & Area of Each tray & 17 & $A_{t}$ & $0.625 \mathrm{~m}^{2}$ \\
\hline & & Length of tray & & $\mathrm{L}_{\mathrm{t}}$ & $1.5 \mathrm{~m}$ \\
\hline & & Width of each tray & 18 & $\mathrm{~W}_{\mathrm{t}}$ & $0.42 \mathrm{~m}$ \\
\hline \multirow[t]{2}{*}{9.} & & Chilli at dryer & & & \\
\hline & & Chilli at open sun & & & \\
\hline
\end{tabular}

Table- IV: Temperature, Relative Humidity, Airflow, \& Solar Radiation

\begin{tabular}{|c|c|c|c|c|c|c|c|}
\hline Time & $\begin{array}{c}\text { Ambient } \\
\text { Temp. } \\
\left({ }^{0} \mathrm{C}\right)\end{array}$ & $\begin{array}{c}\text { Ambient Relative } \\
\text { Humidity } \\
(\%)\end{array}$ & $\begin{array}{c}\text { Upper } \\
\text { Tray } \\
\text { Temp. } \\
\left({ }^{0} \mathrm{C}\right) \\
\end{array}$ & $\begin{array}{c}\text { Lower Tray } \\
\text { Temp. } \\
\left({ }^{0} \mathrm{C}\right)\end{array}$ & $\begin{array}{c}\text { Exhaust } \\
\text { Temp. } \\
\left.{ }^{0} \mathrm{C}\right)\end{array}$ & $\begin{array}{c}\text { Exhaust Relative } \\
\text { Humidity }\end{array}$ & $\begin{array}{c}\text { Solar } \\
\text { Radiation } \\
\left(\mathrm{W} / \mathbf{m}^{2}\right)\end{array}$ \\
\hline $\begin{array}{c}9: 00 \\
\text { am }\end{array}$ & 29.3 & 79.3 & 40.3 & 36.2 & 40.2 & 62.3 & 151.4 \\
\hline $10: 00 \mathrm{am}$ & 30.4 & 77.5 & 42.7 & 38 & 39.4 & 61.5 & 160.2 \\
\hline $11: 00 \mathrm{am}$ & 31.5 & 72.1 & 49.2 & 40.4 & 44.3 & 51.6 & 179.4 \\
\hline $12: 00 \mathrm{pm}$ & 33.9 & 67.2 & 47.6 & 46.1 & 46.5 & 41.5 & 211.15 \\
\hline $1: 00 \mathrm{pm}$ & 35.5 & 63.4 & 60.1 & 47.9 & 54.2 & 37.2 & 233.22 \\
\hline 2:00 pm & 35.3 & 60.4 & 57.5 & 50.6 & 54.6 & 32.9 & 225.19 \\
\hline 3:00 pm & 34.1 & 62.4 & 50.6 & 51.5 & 46.9 & 48.5 & 195.5 \\
\hline 4:00 pm & 32.2 & 54.4 & 51.9 & 43.8 & 48.6 & 41.1 & 162.4 \\
\hline 5:00 pm & 32.3 & 61.7 & 45.2 & 42.9 & 42.8 & 49.3 & 149.3 \\
\hline 6:00 pm & 32.2 & 75.2 & 36.7 & 37.5 & 31.8 & 75.1 & 108.8 \\
\hline Mean & 31.0 & 68.04 & 48.37 & 43.59 & 44.5 & 49.8 & 178.6 \\
\hline
\end{tabular}

\section{Published By:}

Blue Eyes Intelligence Engineering \& Sciences Publication

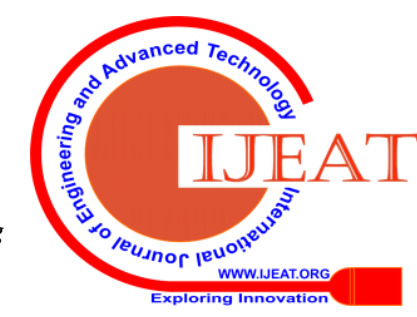


Table- V: S/N Ratio

\begin{tabular}{|c|c|c|c|c|}
\hline $\begin{array}{c}\text { Ambient } \\
\text { Temp }\end{array}$ & $\begin{array}{c}\text { Ambient } \\
\text { Relative } \\
\text { Humidity }\end{array}$ & $\begin{array}{c}\text { Exhaust } \\
\text { Temp. }\end{array}$ & $\begin{array}{c}\text { solar } \\
\text { Radiation }\end{array}$ & S/N Ratio \\
\hline 33.9 & 63.2 & 46.5 & 211.15 & 46.49182 \\
\hline 33.9 & 67.4 & 54.2 & 215.35 & 46.6629 \\
\hline 33.9 & 60.4 & 54.6 & 213.41 & 46.5843 \\
\hline 35.5 & 63.2 & 54.2 & 229.62 & 47.22019 \\
\hline 35.5 & 67.4 & 54.2 & 233.22 & 47.35532 \\
\hline 35.5 & 60.4 & 46.5 & 230.14 & 47.23984 \\
\hline 35.3 & 63.2 & 54.6 & 227.32 & 47.13275 \\
\hline 35.3 & 67.4 & 46.5 & 228.84 & 47.19064 \\
\hline 35.3 & 60.4 & 54.6 & 225.19 & 47.05098 \\
\hline
\end{tabular}

Table- V: Response Table for Signal to Noise Ratios (Larger is better)

\begin{tabular}{|c|c|c|c|}
\hline & Ambient & $\begin{array}{c}\text { Ambient } \\
\text { Relative } \\
\text { Level }\end{array}$ & $\begin{array}{c}\text { Humidity } \\
\text { Exhaust } \\
\text { Temp. }\end{array}$ \\
\hline 1 & 46.58 & 46.96 & 46.97 \\
\hline 2 & 47.12 & 46.95 & 47.08 \\
\hline 3 & 47.27 & 47.07 & 46.92 \\
\hline Delta & 0.69 & 0.12 & 0.16 \\
\hline Rank & 1 & 3 & 2 \\
\hline
\end{tabular}

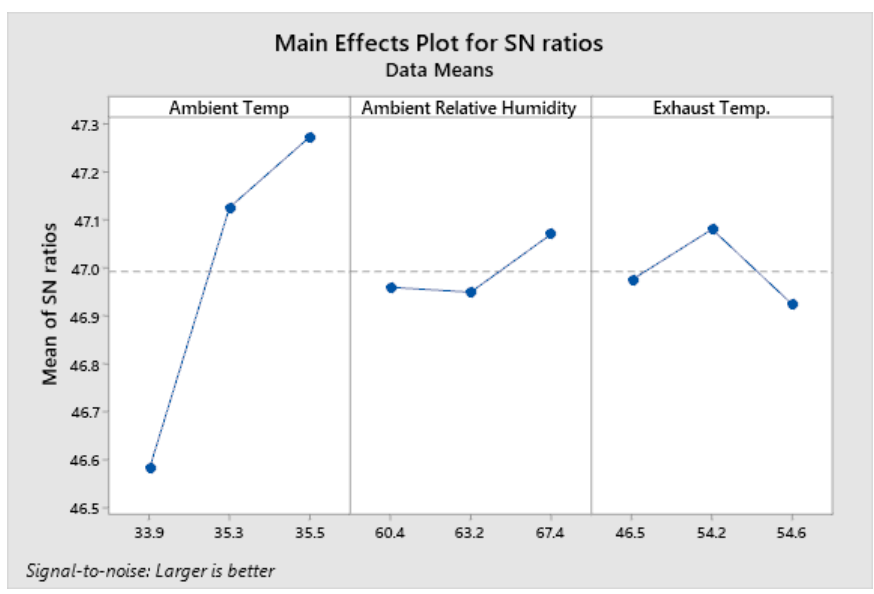

Fig. 3.Plot for S/N Ratio

\section{CONCLUSION}

In this present study an elaborated survey on solar based system and its development is performed. Solar applications are slowly increasing as it is more profusely available renewable source of energy which has high effectiveness and usefulness in development of a nation which is pollution free. Many researches are till now getting established in this direction to have a newer developments using solar energy. In this study of survey a step towards finding a way of work in the further direction is carried out. The study concludes that in between all the developed methods Taguchi is the most suitable method to develop new parameters for the development in the field of solar based application as it gives suitable values for future betterment of solar devices.
The experiment is effectively carried out and the outcomes were reported every hour. The outcomes depict that radiations of the sun are maximum at $1 \mathrm{pm}$ with a value of $233.22 \mathrm{~W} / \mathrm{m} 2$. Further, from the Taguchi method, the required $\mathrm{S} / \mathrm{N}$ ratios developed for the parameters such as flow of air, velocity of air as well as humidity present. The graphs which are formed by the developed techniques shows that the optimized result has value for Ambient temperature as 35.5 OC value of air velocity Ambient Relative Humidity as 67.4(\%)and Exhaust temperature as $54.2 \mathrm{OC}$ at the time of $1: 00 \mathrm{pm}$.

\section{REFERENCES}

1. Chabane, F., Bensahal, D., Brima, A., \& Moummi, N. (2019). Solar drying of drying agricultural product (Apricot). Mathematical Modelling of Engineering Problems, 6(1), 92-98. https://doi.org/10.18280/mmep.060112

2. Dhumne, L. R., Vipin Bipte, E. H., \& Jibhkate, Y. M. (2016). Optimization of Solar Tunnel Dryer Using Genetic Algorithm. International Research Journal of Engineering and Technology, 2395-56.

3. Hammond, L., Bai, L., Sheehan, M., \& Walker, C. (2018). Experimental Analysis and Diffusion Modelling of Solar Drying of Macroalgae - Oedogonium sp . CHEMICAL ENGINEERING TRANSACTIONS https://doi.org/10.3303/CET1865072

4. K, S. K., Shivashankar, U., G, H. G., \& Shekar, K. (2019). Hybrid Solar Fruit Dryer. International Research Journal of Engineering and Technology (IRJET), 6(5), 6778-6782.

5. Khama, R., Aissani, F., \& Alkama, R. (2016). Design and performance testing of an industrial-scale indirect solar dryer. Journal of Engineering Science and Technology, 11(9), 1263-1281.

6. Macías-ganchozo, E. R., Bello-moreira, I. P., Trueba-macías, S. L., Enrique, X., Anchundia-muentes, M. E., \& Bravo-moreira, C. D. (2018). Design , development and performance of solar dryer for pineapple ( Ananas comosus ( L .) Merr .), mamey ( Mammea americana L .) and banana ( Musa paradisiaca L .) fruit drying. Agroindustry and Food Science, 67, 30-38.

7. Majdi, H., \& Esfahani, J. A. (2018). Energy and drying time optimization of convective drying: Taguchi and LBM methods. Drying Technology, $0(0), \quad 1-13$ https://doi.org/10.1080/07373937.2018.1458036

8. Monteiro, R. L., Carciofi, B. A. M., \& Laurindo, J. B. (2016). A microwave multi-flash drying process for producing crispy bananas. Journal of Food Engineering, 178, 1-11. https://doi.org/10.1016/j.jfoodeng.2015.12.024

9. N., N., Tidke, V., \& N, T. B. (2016). Microbial and biochemical analysis of dried fish and comparative study using different drying methods. Drying Technology, 35(12), 1480-1491.

10. Ndukwu, M. C., \& Bennamoun, L. (2017). Potential of integrating Na $2 \mathrm{SO} 4.10 \mathrm{H} 2 \mathrm{O}$ pellets in solar drying system Potential of integrating Na2SO4 . 10H2O pellets in solar drying system. Drying Technology, 3937(August). https://doi.org/10.1080/07373937.2017.1366506

11. Obayopo, S. O., \& Alonge, O. I. (2018). Development and Quality Analysis of a Direct Solar Dryer for Fish. Food and Nutrition Sciences, 09(05), 474-488. https://doi.org/10.4236/fns.2018.95037

12. Osodo, B., \& Nyaanga, D. (2018). Investigating the Effect of Selected Parameters on Moisture Removal Rate of an Experimental Forced Convection Solar Grain Dryer. International Journal of Energy Engineering, 8(1), 12-18. https://doi.org/10.5923/j.ijee.20180801.02

13. Padmanaban, G., \& Palani, P. K. (2017). Grey Relation Analysis of Solar Drying Process Parameter on Copra. Ital. J. Food Sci, 29, 434-442.

14. Salvatierra-Rojas, A., Nagle, M., Gummert, M., de Bruin, T., \& Müller, J. (2017). Development of an inflatable solar dryer for improved postharvest handling of paddy rice in humid climates. International Journal of Agricultural and Biological Engineering, 10(3), 269-282. https://doi.org/10.3965/j.ijabe.20171003.2444

15. Vásquez, J., Reyes, A., Mahn, A., \& Cubillos, F. (2016). Experimental evaluation of fuzzy control solar drying with thermal energy storage system. Drying Technology, 34(13), 1558-1566. https://doi.org/10.1080/073739 $\underline{37.2015 .1137001}$

\section{Published By:} Blue Eyes Intelligence Engineering \& Sciences Publication

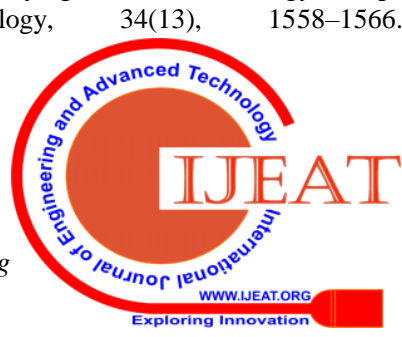


16. Zebib, H., Teame, T., \& Meresa, T. (2017). Evaluation of solar dryers on drying and sensory properties of salted Tilapia filets, Tigray, Northern Ethiopia. ISABB Journal Of Food And Agriculture Science, 7(2), 10-18. https://doi.org/10.5897/ISABB-JFAS2017.0065

\section{AUTHORS PROFILE}

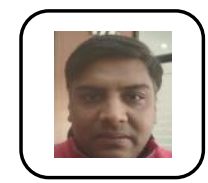

Dr. Ankit Bansal is working as Associate Professor in the Dpeartment of Electrical Engineering . He holds Master's Degree and Ph.D in the same domain. He has 17 years of Acadmic experience

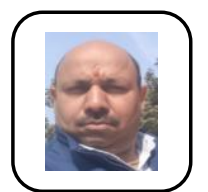

Dr. Umesh Gupta is working as Associate Professor in the Dpeartment of Mechanical Engineering. He holds Master's Degree and Ph.D in the same domain. He has a total of 21 years of Academic Experience. He has expertise in Production Engineering.

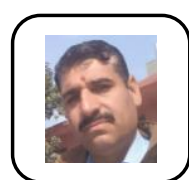

Sandeep Singh is working as Assistant Professor in the Department of Electrical Engineering. He holds Master's Degree and Ph.D in the same domain. He has 13 years of Academic experience.

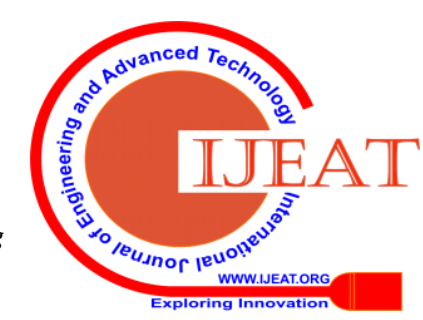

